\title{
Relationship between Emotional Engagement and Academic Achievement among Kenyan Secondary School Students
}

Erick Wara

Kisii-Kenya

\section{Dr Peter JO Aloka}

Department of Psychology \& Educational Foundations, Jaramogi Oginga Odinga University of science \& technology

\section{Dr Benson Charles Odongo,}

Department of Early childhood Education Studies, Jaramogi Oginga Odinga University of science \& technology

Doi: 10.2478/ajis-2018-0011

\section{Abstract}

The purpose of this study was to investigate the relationship between emotional engagement and academic achievement among secondary school students of Manga Sub County, Nyamira County, Kenya. The study was hinged on the Self Determination theoretical perspective. The concurrent triangulation design of the mixed methods approach was employed. From the target population of 1750 form four students, 35 Principals and 35 Guidance and Counselling teachers, 316 students, 11 Principals and 11 Guidance and counselling teachers, and 11 student leaders were randomly sampled for the study. Questionnaires were used to collect data from the students, while interview schedules were used to collect data from Principals, Guidance and Counselling teachers and student leaders. The face validity of the research instruments was determined by experts from the department of Psychology and Educational Foundations of Jaramogi Oginga Odinga University of Science and Technology. Reliability was ascertained by the internal consistency method using Cronbach's alpha, and a reliability coefficient of 0.849 was obtained for the questionnaire. Inferential statistics from quantitative data were analyzed using Pearson's Product correlation and regression analysis with the aid of the statistical package for social sciences (SPSS) version 22. Qualitative data from interviews were analyzed thematically. The study revealed that there was a statistically significant moderate positive correlation $(r=.354, N=312, p<.05)$ between emotional engagement and academic achievement among the students, with an increase in emotional engagement occasioning an improvement in academic achievement. The study recommended that teacher counsellors should adopt appropriate therapy techniques geared towards the enhancement of emotional engagement of all students in the schools of their jurisdiction in order to boost their chances of doing better in their studies.

Keywords: relationship; emotional engagement; academic achievement; secondary school; students

\section{Introduction}

According to Mageka and Mahonge (2013), education is considered a necessity from many perspectives in all countries around the world. From the overall socioeconomic point of view, education is an investment in creating a competitive labour force that is important in attracting 
foreign investment. Yet, others see education as a human right, which everybody must have access to for increasing capacities of individuals to lead to the life they value and participate in all socioeconomic aspects of life. However, success in the field of education the world over is bedeviled with one fundamental impediment: poor performance. Many schools the world over suffer disproportionately with among other manifestations, low academic achievement among students (Rumberger, 2008).

In Africa, Evoh (2007) notes that secondary education has continued to face several setbacks. There are challenges to with the quality of instruction, the size of classes, availability of up- to- date materials and equipment, the relevance of the curriculum to current conditions, poor performance and the integration of higher education with the world of work.

In East Africa, very poor economic conditions have characterized, and hence negatively influenced the provision of education at all levels (Evoh, 2007). Indeed, in subscribing to the ideals of the New Partnership for Africa's Development (NEPAD), even the East African countries concurred with the rest of the continent that improved secondary education is fundamental to the creation of effective human capital in any country (Evoh, 2007). However, together with the World Bank, the East African countries' scholars agree that the biggest task confronting education policymakers in this part of the world is how to transform secondary education institutions and current schooling practices to align them with the fast growing demands of globalization and the technology-driven world.

One of the factors that has been identified that could be key in transforming students' approach to their studies is student engagement. Akey (2006) defines engagement as the level of participation and intrinsic interest that a student shows in school and further observes that engagement in schoolwork involves both behaviors (such as persistence, effort, attention) and attitudes (such as motivation, positive learning values, enthusiasm, interest, and pride in success). Thus, engaged students seek out activities, inside and outside the classroom, that lead to success or learning. Student engagement can improve students' academic performance, promote school attendance and inhibit risky youth behaviors (Al-Alwan, 2014; Weiss and Garcia 2012).

Student engagement is typically described as having multiple components (Perry, 2008; Abbing, 2013) and based on the work of Fredrick, Blumenfeld, and Paris (2004), emotional engagement refers to the feelings, interests, and attitudes that students have toward learning and school. Emotionally engaged students display curiosity, a desire to know more and positive emotional responses to learning and school.

Purdul, Chege, and Thinguri (2014) report that in Kenya, among the factors contributing to poor performance in most secondary schools include lack of effective engagement of students in academic work. This is despite the fact that the provision of Free Day Secondary Funds by the government should have seen fewer students being sent home for fees, and meaning that teacherstudent contact hours should have gone up, yet still most secondary schools continue to perform disappointingly. Existing literature on student engagement point to the fact that even though it is hypothesized to be one of the strongest factors affecting achievement, emotional engagement is the least frequently studied form of engagement in motivation research (Wormington, Corpus, \& Anderson, 2011; Martin \& Dowson, 2009; Sagayadevan \& Jeyaraj, 2012; Fredricks et al., 2004). Among the scholars in this area, Mo and Singh (2008) conducted a study whose findings revealed that emotional engagement had a significant overall effect $(\beta=.004$, indirect; $\beta=.10$ direct, $\beta=.14$ overall) on academic achievement. In the study by Rodriguez and Boutakidis (2013), emotional engagement was found to be a significant positive predictor of GPA for second generation $(p=$ .003 ) and third generation ( $p=.029)$ students, but wasn't a significant predictor of GPA for first generation students $(p=.641)$. While Mauro (2014), in his qualitative research survey in the U. S. reported that students who received encouragement and empathy from teachers were motivated in school, Gray and DiLoreto (2016) found that student satisfaction and perceived learning, shared a strong relationship $(r=.85, \rho<.01)$. Further, Lee (2014), whose target population of PISA 2000 (OECD, 2000) in the United States, found that the direct effect of emotional engagement on reading was 0.037 , the indirect effect was 0.019 , and the total effect (equivalent to the sum of direct and indirect effect) was 0.056 , meaning that students with higher levels of emotional engagement had significantly higher reading scores than students with lower levels of emotional engagement. 
Sagayadevan and Jeyaraj (2012) revealed that emotional engagement significantly predicted perceived learning, $\beta=.48, p<.001$, similar to Kamla- Raj and Ugur (2015), who, in their study in Turkey, employed correlational design in the research conducted with 578 students and discovered that the academic performance of the students had a positive relationship with emotional engagement $(r=.19)$.

Mai and Alhoot (2016) did a study whose path analysis results indicated that a significant positive relationship existed between the students' engagement and their achievement in science $(\beta=11.491 ; C R=4.196 ; P=.000<.05)$, and Afzal and Afzal (2015), in their study, revealed that the satisfaction level $(\bar{X}=43.55)$ of public school students was high but their achievement scores $(\bar{X}=57.70)$ were low, while the satisfaction level $(\bar{X}=39.89)$ of private school students was low but their achievement scores $(\bar{X}=68.64)$ were high. In a study in Nigeria, the multiple prediction design was applied by Kpolovie, Joe and Okoto (2014) to ascertain the magnitude of relationship and prediction that students' interest in learning and attitude to school individually and collectively have on their academic achievement. The results revealed that there was overwhelming evidence that students' attitude to school and interest in learning significantly predicted their academic achievement, accounting for as much as $21.6 \%$ of the variance in the criterion. Similarly, Akomolafe and Adesua (2015) did a study that showed that there was a significant relationship between classroom environment and the academic performance of senior secondary school students and Dhaqane and Afrah (2016) revealed a strong relationship between Satisfaction of Students and Academic Performance among the students they studied. Just as Okita (2014) revealed that there was a positive and significant relationship between attitude toward career and academic performance $(r=.336, p<0.01)$, Syokwaa, Aloka and Ndunge (2014) conducted a study that showed that there was a correlation between anxiety levels and academic achievement, and specifically that high anxiety levels had a negative impact on the quality of academic results recorded by students.

\section{Research Methodology}

The study employed the concurrent triangulation design of the mixed methods approach. The concurrent triangulation approach is generally used for a variety of reasons centering on the need to bring together different but complementary kinds of data evidence to corroborate results or identify discrepancies between data sources or to use one form of evidence to expand on the results of the other (Plano-Clark, Huddleston-Casas, Churchill, O'Neil Green, and Garrett, 2008). Quantitative data in this study were collected using the questionnaire for students, while interview schedules were used to gather data from Principals, Guidance and Counselling teachers and student leaders. The collected information was integrated in the process of interpreting the overall results, and the strategy was envisioned to result in well-validated and substantiated findings.

This study embraced the mixed methods paradigm because of the pragmatic worldview that is the philosophical assumption adopted here; pragmatic in the sense that the concern in this study was with actions, situations and consequences which are working, rather than antecedents to the study interests as say, covered in post positivism. Creswell (2009), arguing for the mixed methods approach, observes that it is useful when either the quantitative or qualitative approach by itself is inadequate to best understand a research problem or the strengths of both quantitative and qualitative research can provide the best understanding. It was thus used in the sourcing, interpretation, and analysis of the data in this study, based on the premise outlined by Creswell (2009).

\section{Findings and Discussion}

The findings on the relationship between emotional engagement and academic achievement were consolidated from both the quantitative data obtained from the students and the qualitative data generated from interview respondents. Since the concentration on emotional feelings is one of the hallmarks of guidance and counselling, these findings should have far reaching implications for guidance and counselling personnel in secondary schools. Table 1.0 presents the responses 
solicited from students in this regard.

Table 3.1: Views of the Respondent Students on Emotional Engagement

\begin{tabular}{|c|c|c|c|c|c|c|c|}
\hline Statements & SA & $\mathrm{A}$ & NS & $\mathrm{D}$ & SD & Mean & Std Dev. \\
\hline \multirow{6}{*}{$\begin{array}{l}\text { I feel safe in this school. } \\
\text { My opinions are respected in this school. } \\
\text { If I could choose a high school now, I } \\
\text { would choose this school. } \\
\text { I am never bored in class. } \\
\text { I have never considered dropping out of } \\
\text { this school. } \\
\text { I am an important part of this school. } \\
\text { Overall, I feel good about being in this } \\
\text { school. }\end{array}$} & $\begin{array}{l}87(27.9 \%) \\
84(26.9 \%)\end{array}$ & $\begin{array}{l}159(51.0 \%) \\
153(49.0 \%)\end{array}$ & $\begin{array}{l}54(17.3 \%) \\
50(16.0 \%)\end{array}$ & $\begin{array}{c}3(1.0 \%) \\
17(5.4 \%)\end{array}$ & $\begin{array}{l}9(2.9 \%) \\
8(2.6 \%)\end{array}$ & $\begin{array}{l}4.00 \\
3.92\end{array}$ & $\begin{array}{l}0.87 \\
0.93\end{array}$ \\
\hline & $75(24.0 \%)$ & $151(48.4 \%)$ & $66(21.2 \%)$ & $7(2.2 \%)$ & $13(4.2 \%)$ & 3.86 & 0.95 \\
\hline & $80(25.6 \%)$ & $162(51.9 \%)$ & $36(11.5 \%)$ & $14(4.5 \%)$ & $20(6.4 \%)$ & 3.86 & 1.05 \\
\hline & $93(29.8 \%)$ & $142(45.5 \%)$ & $58(18.6 \%)$ & $12(3.8 \%)$ & $7(2.2 \%)$ & 3.97 & 0.92 \\
\hline & 78 (25\%) & $162(51.9 \%)$ & $63(20.2 \%)$ & $0(0.0 \%)$ & 9 & 3.96 & 0.84 \\
\hline & $80(25.6 \%)$ & $174(55.8 \%)$ & $42(13.5 \%)$ & $8(2.6 \%)$ & $8(2.6 \%)$ & 3.99 & 0.85 \\
\hline
\end{tabular}

Source: Survey data (2017)

From the views of respondents as shown in Table 1.0, the findings of the study indicated that many of the students felt that they were adequately emotionally engaged in the learning process. First, nearly four fifths [246 (78.8\%)] of the students (87 of them, $27.9 \%$ strongly agreed, and 159 , or $51.0 \%$ agreed) who participated in the survey confirmed that they felt safe in their school. This item attracted the highest mean of 4.00 (Std. Dev. =.87), indicating that many respondents were in agreement with the statement: "I feel safe in this school". Only 54 of them (17.3\%) were not sure, with another minority of $3(1.0 \%)$ disagreeing, and $9(2.9 \%)$ strongly disagreeing.

A feeling of safety in school is one of the epitomes of child-friendly school environments, which should foster a conducive learning environment for the sake of academic success. Thus, in circumstances where majority of the students feel safe in their school environments, they are expected to concentrate more on their studies. This is in tandem with the findings of Mauro (2014) whose study participants reported that receiving empathy from teachers motivated them in school. It also concurred with Abbing (2013) who reported that the interaction effect between students' satisfaction and language and math outcomes was positively significant among a cohort of students studied.

Qualitative data from the Principals and Guidance and counselling teachers interviewed revealed that in their schools, there were attempts to foster child-friendly environments, where all students were consciously encouraged to participate actively in the affairs concerning their studies. They would freely be incorporated in planning every activity that involves their participation. One principal reported:

"The inculcated child-free environment gives them the confidence to approach every matter, including academics" (Principal 11)

From the student leaders, one said:

'The teachers always strive, particularly our Principal, to make our environment very conducive for learning. This makes us feel confident and hence approach our studies with energy' (student leader 4)

The implication of these two excerpts is that the confidence thus generated in the students should translate into greater effort in studies, and ultimately academic success. One of the teachers interviewed also concurred with this and said:

"The learning environment is learner-friendly; hence, students feel safe enough to focus entirely on their academic work, and they get a chance to improve their academic performance" (Teacher 8)

Evidenced by the above excerpts, the conviction by the teachers is that a learner-friendly environment is a precursor to improved academic performance, and hence should be fostered as much as possible in the learning institutions. These findings concurred with Lee (2014) who observed that students with higher levels of emotional engagement had significantly higher reading 
scores than those with lower levels of emotional engagement.

Regarding whether their opinions were respected in the school, a total of $237(75.9 \%)$ of the students either strongly agreed (84 of them, $26.9 \%$ ), or just agreed (153, or $49.0 \%$ ), while only 25 of them $(8 \%)$ disagreed. This was an indication of the high levels of confidence and probably satisfaction that the students had with their schools. The item mean was a high of 3.92, with a standard deviation of 0.93 . This kind of picture is a reassuring experience to students in any institution, and makes them own their learning environment, which is a necessary ingredient for concentrated effort in studies. It is also itself therapeutic, and provides a springboard for the smooth operations of the Guidance and Counselling team in the sense that when students feel that their opinions are respected, they may easily develop a sense of attachment to their environment. Mauro (2014) also found that students feel very comfortable when teachers appear sympathetic when the students have made mistakes, and they may seek more help and engage in class because they feel understood by teachers. Similarly, Gray and DiLoreto (2016) found a strong relationship between student satisfaction and perceived learning.

Qualitative data from the guidance and counselling teachers corroborated the concept of respect for students' opinions. One teacher said:

'In our school, we have barazas every term, where students express their opinions in an open

forum. They are listened to, and their issues are addressed according to their concerns.' (Teacher11.)

This excerpt reinforced the fact that if authorities provided students with an opportunity to express their feelings, there are possibilities of the students feeling free and having their concerns addressed. This would boost their confidence in the school, and hence enable them focus their energies on their studies. This finding was in agreement with that of Wonglorsaichon et.al. (2014) who found that emotional engagement in the form of positive emotion had a positive relationship with learning achievement by students.

Tellingly, while an apparent majority of 226 students (72.4\%) agreed with the statement "If I could choose a high school now, I would choose this school", a significant, though not big proportion (66 of them, or $21.2 \%$ ) were not sure whether they would do so. Another 7 student respondents $(2.2 \%)$ disagreed, while $13(4.2 \%)$ strongly disagreed. With the item mean at 3.86 and a standard deviation of 0.95 , this was a clear indication that though most circumstances would guarantee students' emotional satisfaction in the studied schools, there could still be other salient factors that some would consider in determining where they would want to continue learning in their current schools. This finding seemed to cement those of Rodriguez and Boutakidis (2013) who reported that students' feelings of belonging and emotional reactions toward teachers, staff and the school positively predicted the GPA, particularly for second and third generation immigrant Mexican American students.

Qualitative data sourced from the Guidance and Counselling teachers and student leaders further emphasized the importance of creating an environment that fosters students' love for their schools. One teacher said:

'One of the biggest interests in our school is to inculcate a feeling of belonging to the school in the students. This is through our strife towards instilling a learner-friendly environment that responds to every student's needs.' (Teacher 5)

'Majority of us love our school so much, courtesy of the massive efforts put in place by our teachers, and most importantly, our Principal' (Student Leader 1)

These excerpts point to the fact that there are conscious measures taken by schools to ensure students do not drop out, even if sometimes they may not have every other facility. Principally, a greater part of the inculcation of such feelings is the duty of the counselling teacher. Mauro (2014) also reported that students who received encouragement and empathy from teachers motivated them to learn in school.

As an expression of how interesting they found their schools, a significant proportion [242 $(77.5 \%)]$ of the students indicated that they were never bored in their class. This figure was drawn from 80 (25.6\%) who strongly agreed, and 162 (51.9\%) who agreed with the statement:" I am never 
bored in class." They largely outmuscled the $34(10.9 \%)$ of them who indicated that they were usually bored while in class, while $36(11.5 \%)$ remained non-committal on whether or not they would get bored in class. The fact that majority never got bored in class was a strong indication of how satisfying the school environments were in the surveyed schools. Consequently, the students in those schools would be expected to approach their studies with seriousness and it is anticipated that this would be a boost to their performance. This finding was in sync with the study by Kpolovie, Joe and Okoto (2014) who found overwhelming evidence that students' attitude to school and interest in learning significantly predicted their academic achievement, accounting for as much as $21.6 \%$ of the variance in the criterion. Suleman and Hussain (2014) also agreed with this finding when they reported that a favourable classroom environment has a significant positive effect on the academic achievement of secondary school students, though according to Lawrence and Vimala (2012), there was no relationship between school environment and academic achievement of students.

Aside from the students' own perspectives, it was revealed from the qualitative data generated in this study that schools had their systems of intensifying students' emotional engagement and hence ameliorating their chances of achieving academic excellence. The respondents mentioned the use of the suggestion box, guest speakers, guidance and counselling, school barazas and the promotion of child-friendly environment.

It also emerged that guest speakers including professionals in diverse fields were invited to talk to students about their various professions and their importance. These people give confidence to students that with focus, they can achieve their dreams. One teacher said:

'Guest speakers like pastors are invited for them and various other professionals like medics. This attempt gives them the confidence to like their studies and hence work hard' (Teacher 2)

The excerpt above implied that the students would get inspired by these guests, and the motivation hence generated from their talks would make students feel the need to put in more effort in their studies. At the same time, such are programmes that would introduce the students to the various professions to be pursued after high school. This kind of sensitization would be expected to engender hard work, and subsequently, academic excellence. From the literature, Okita (2014) found a positive and significant relationship between attitude toward career and academic performance, hence supported this line of thinking, together with Mai and Alhoot (2016) who found a significant positive relationship between students' emotional engagement, self esteem and their achievement in science.

Further, the results indicated that three quarters $235(75.3 \%)$ of the students who participated in the study said that they had never considered dropping out of their school at any one time. This majority seemed to pass a vote of confidence on their schools and the programmes going on there. This was in contrast with the $58(18.6 \%)$ who were not sure, $12(3.8 \%)$ who disagreed, and 7 $(2.2 \%)$ who strongly disagreed with that statement. This means that only a minority of $19(6 \%)$ had considered dropping out of school. From a counselling point of view, however, those 19 would require intervention in order to assist them to settle down. In determining the students' levels of concentration on their studies, this finding was significant, particularly considered against those of Gray and DiLoreto (2016) who found student satisfaction to have a very strong relationship with perceived learning. Similarly, Abbing (2013) reported a strong positive relationship between satisfaction in school and actual students' outcomes.

Qualitative data obtained from the Principals and Guidance and Counselling teachers revealed that one of the strategies of developing the necessary confidence in school is the use of class meetings. These are sessions when class members meet their class teachers and discuss issues related to teaching and learning within the respective classes or streams. They are usually geared towards providing confidence to the students and to make them love their school and the general learning environment. This is because the more they are able to air their views, the more chances there are that they will be listened to, and the matters that are most dear to them or those that are troubling them, are listened to and sorted out. As a result of the confidence developed, they would put in more effort in their studies and yield better academic results. This was eloquent in one Principal's account: 
'Through class meetings, students are encouraged to give and share their feelings freely, and these opinions are highly respected. This has enabled them to feel part of the whole school system and hence the confidence to face school tasks' (Principal 2)

The student leaders had this to say:

'We are fortunate to hold regular meetings as classes, meetings which sometimes class teachers attend. We express our feelings freely, and the administration listens to us. Consequently, we gain confidence in our shool, studies, and hence improve academically' (Student leader 10)

The contents of these excerpts implied that students feel comfortable in a system that fosters free and open communication as a means of interaction, and for the sake of developing the confidence to face issues. From the counselling point of view, this would be key in instilling selfesteem in the learners, hence a more proactive approach to life's issues. Sagayadevan and Jeyaraj (2012) also found that individuals in the 'good' interaction condition had significantly higher emotional engagement scores, compared to those in the 'poor' interaction condition. Similarly, Akomolafe and Adesua (2015) found a significant relationship between classroom environment and academic performance.

Regarding the statement: "I am an important part of this school", although it was established that majority (mean=3.96; Std Dev. $=.84$ ) of the students who took part in the survey (78 strongly agreed, forming $25 \%$, , a significant proportion others $63(20.2 \%)$ expressed doubt on whether they were really valued in their school. It came out that only $25(8 \%)$ of the students who took part in the study believed that their opinions were not respected in their schools, but $153(75.9 \%)$ of them were of the general belief that their opinions were respected. The importance of this feeling of importance in the school was also expressed by Abbing (2013) who revealed that the affective component of student engagement, indicated by the student's reported satisfaction, social relations and teacher support showed distinct patterns of relationships with language and math outcomes. In fact, to underscore the contribution of students' emotional satisfaction, Syokwaa, Aloka and Ndunge (2014) proved that there was a correlation between anxiety levels and academic achievement, with a specific rider that high anxiety levels had a negative impact on the quality academic results recorded by secondary school students.

Information cementing the aspect of valuing students' opinions was best expressed in the qualitative data that was sourced from the Principals. Some of the Principals said that as a measure of instilling a sense of belonging and hence emotional engagement of the students, they held what they referred to as the Principal's forum, where the Principal would meet the students of the whole school. $\mathrm{He} /$ she would address them on the emerging issues in the course of their studies, listen to their concerns, and make the necessary clarifications regarding various policies implemented. The forum would also be used to update the students on government policies in order to keep them abreast with important national issues, particularly those impacting on their lives directly. The intention is to make them develop close bonds, be informed, and to instil confidence in them that they can be listened to by none other than the principal, at a very close range. The subtle impact is to have them translate the derived confidence into the approach of examinations and hence pass. In this respect, one Principal said:

"They (students) are encouraged through the principal's forum. This improves their self-esteem and makes them take their academic work seriously." (Principal 8)

From this excerpt, it emerged that proactive principals needed to create open fora to give them opportunity to interact freely with their students, and to give the students the chance to speak where their leaders are. As a sense of instilling self-esteem, this finding agreed with Mai and Alhoot (2016) who found a significant positive relationship between self-esteem, loneliness and engagement and children's achievement in science.

In the consideration of the general psychological settlement in their schools, majority of the students indicated their full satisfaction with their school environments. Whereas only a total of 16 $(5.2 \%)$ of the students held a contrary opinion (8, or $2.6 \%$ disagreed, and another 8 , or $2.6 \%$ strongly disagreed), a significant majority of $254(81.4 \%)$ of them said that they were generally feeling good about being in their school. This was from $80(25.6 \%)$ who strongly agreed, and 174 
(55.8\%) who agreed with the statement "Overall, I feel good about being in this school". Only 42 $(13.5 \%)$ were not sure. This implied that majority believed that things were good in their schools, and could hence exert themselves with ease on their studies. These findings on the levels of confidence in the schools by students were supported by Payton et.al. (2008) who reported the importance of social and emotional learning by families and schools as an effective means of intensifying student satisfaction with school and hence reducing problem behaviours and poor performance. The result, hence, would be positive adjustment and enhanced academic performance. However, the findings tend to disagree with Lawrence and Vimala (2012) who showed that there was no significant relationship between the school environment and academic achievement of standard IX students.

Guidance and Counselling programmes, as qualitative data revealed, were widely used in schools as interventions for behavioural challenges as well as motivation for success. One teacher said:

"During Guidance and counselling sessions, the students are made free to give their views, present their challenges and possibly find solutions to these challenges. The environment in the school is hence made friendly to them, to make them like being in school despite the challenges from home. This is in recognition of the fact that with the many challenges they face, if they become absent, their performance is affected" (Teacher 3)

The excerpt pointed first to one fundamental aspect of counselling: that the client should be assisted to come up with their own solutions to matters pertaining to their challenges. As a consequence, the counselling environment is meant to provide just the enabling environment for the realization of this, through the provision of the core conditions of unconditional positive regard, empathetic understanding, and congruence, or honesty, as propounded by client or person-centred approaches to counselling. The whole school would in turn radiate that enabling environment that would foster academic success, despite the myriad challenges that the students would be facing at home. While this would be in agreement with Usaini et.al. (2015), who found a positive correlation between school environment and academic performance, it would, however, not make sense if compared to the study by Lawrence and Vimala (2012) who found no significant relationship between school environment and academic achievement among standard IX students in Tirunelveli District, India.

Some schools were revealed to have an open forum where students raise issues and get responses in a friendly environment attended by all teachers. This is the concept of baraza. It allows the authorities to address any and every issue regarding the welfare of the students in school. In the process, it makes students get all their concerns listened to, and sorted out. One Principal said:

"In the barazas, their opinions are respected, and the administration tries as much as possible to listen to them, and talk good about them. This raises their self-esteem, and hence their confidence in facing their academic work" (Principal 11)

From the student leaders:

As students, we always look forward to our school baraza. It is an occasion to freely express our views, feel that we have been heard, and listen to the Principal's explanations of our concerns. This boosts our morale, and accelerates our desire for academic success. (Student leader 11)

These excerpts indicate that in some of the school environments, the students enjoy the freedom of interacting with the administration at a close range, outside class hours. This is in order to give them the chance to express their issues without the fear of intimidation, get them addressed, and hence makes them feel energised to do well academically.

All these findings expressing the relationship between emotional engagement and academic achievement concurred with those of Mauro (2014) who found that students who received encouragement and empathy from teachers got motivated in school and ended up doing better. Hence, it would be important for teachers to be keen all the time on their relationship with students in order to ensure that they liked the school. However, the results seemed to contradict those by Sagayadevan and Jeyaraj (2012) who reported that emotional engagement failed to predict 
academic achievement of individuals until a second mediation analysis was done and revealed that emotional engagement significantly predicted perceived learning.

To find out whether there was any significant relationship between cognitive engagement and academic achievement, the null hypothesis was promulgated thus:

$\mathrm{Ho}_{2}$ : There is no statistically significant relationship between emotional engagement and academic achievement among secondary school students in Manga Sub County, Nyamira County.

To test the hypothesis, Pearson Product Moment Correlation Coefficient was computed, with scores on emotional engagement as an independent variable and level of academic achievement as the dependent variable. The students' scores of emotional engagement were converted from the frequency of responses into a continuous scale by calculating mean responses per respondent, with high values indicating high emotional engagement and vice versa. The result of the Pearson Product Moment Correlation Coefficient was as shown in the SPSS output in Table 1.2.

Table 3.2: Relationship between Emotional Engagement and Academic Achievement

\begin{tabular}{llc}
\hline & & Academic achievement \\
\hline \multirow{3}{*}{ Emotional engagement } & Pearson Correlation & .354 \\
& Sig. (2-tailed) & .000 \\
& $\mathrm{~N}$ & 312 \\
\hline \multirow{2}{*}{. Correlation is significant at the 0.01 level (2-tailed). }
\end{tabular}

Table 3.2 indicates that there was a statistically significant moderate positive correlation $(r=.354$, $\mathrm{N}=312, p<.05)$ between emotional engagement and academic achievement among the students, with an increase in emotional engagement occasioning an improvement in academic achievement. Given that the relationship was statistically significant, the hypothesis that, "There is no significant relationship between emotional engagement and academic achievement" was expressly rejected. It was therefore concluded that student emotional engagement has positive influence on the student academic achievement among the cohort that was involved in this study. This result was almost similar to that of Mo and Singh (2008) who found out that emotional engagement had a significant overall effect ( $\beta=.004$, indirect; $\beta=.10$ direct, $\beta=.14$ overall) on academic achievement.

To further demonstrate this relationship in a pictorial way, a scatter plot was generated as shown in Figure 1.

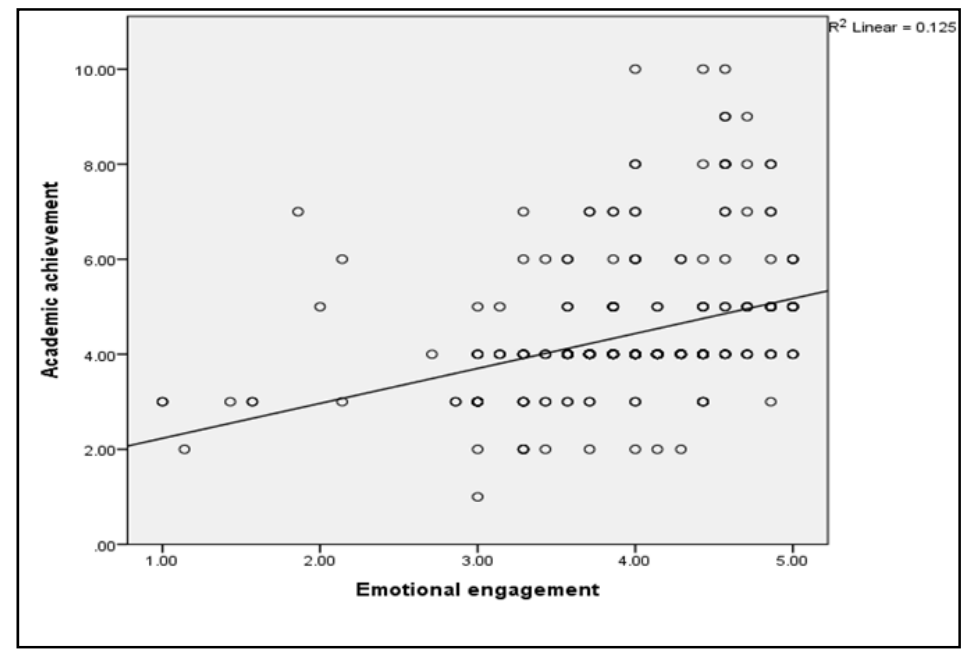

Figure 1: Scatter Plot Depicting the Relationship between Emotional Engagement and Academic Achievement 
The scatter plot shows that there was fairly moderate positive correlation between emotional engagement and academic achievement. There is some evidence that the pattern of dots slopes from lower left to upper right, signifying a positive correlation between the two variables. The coordinate points seem to form some visible pattern, implying that the two data sets were somehow correlating. The line of best fit, which also is sloping to the upper right, further reveals that there are some correlations between the two variables. The scatters inclined to concentrate in the vicinity of the identity line, indicating that the relationship was real and not by chance. This revelation was in agreement with Wonglorsaichon et.al. (2014) who found a high correlation between emotional engagement and academic achievement.

However, to estimate the exact magnitude of influence of emotional engagement on academic achievement, a coefficient of determination $\left(R^{2}\right)$ was worked out. This was done using of regression analysis and the results were as shown in Table 3.3.

Table 3.3: Model Summary on Regression Analysis of Influence of Emotional Engagement on Academic Achievement

\begin{tabular}{ccccc}
\hline Model & $\mathrm{R}$ & $\mathrm{R}$ Square & Adjusted R Square & Std. Error of the Estimate \\
\hline 1 & $.354^{\mathrm{a}}$ & .125 & .123 & 1.29488 \\
\hline a. Predictors: (Constant), Emotional engagement & \\
b. Dependent Variable: Academic achievement $(\mathrm{N}=312)$ &
\end{tabular}

The model revealed that emotional engagement accounted for $12.5 \%$ the variation in the academic achievement among students who were involved in this study, as denoted by the coefficient of determination, $R$ square $=.125$. This was a sizeable effect from one independent variable on the dependent variable.

Further to the above revelations, and in order to determine whether emotional engagement was a significant predictor of academic achievement, Analysis of Variance (ANOVA) was computed as presented in Table 3.4.

Table 3.4: ANOVA -Influence of Emotional Engagement on Academic Achievement

\begin{tabular}{ccccccc}
\hline & Model & Sum of squares & Df & Mean square & $\mathrm{F}$ & Sig. \\
\hline & Regression & 74.516 & 1 & 74.516 & 44.442 & $.000^{b}$ \\
1 & Residual & 519.779 & 310 & 1.677 & & \\
\cline { 3 - 5 } & Total & 594.295 & 311 & & & \\
\hline
\end{tabular}

a. Dependent variable: Academic achievement

b. Predictors: (constant), Emotional engagement $(\mathrm{N}=312)$

From Table 3.4, it was evident that emotional engagement was a significant predicator of academic achievement $[F(1,310)=44.442, p<.05)$. This indicated that emotional engagement indeed influenced academic achievement among secondary school students. It was evident that emotional engagement explains a significant amount of the variance in academic achievement.

Further, still, to the above findings, linear regression was generated to find the actual influence of emotional engagement on academic achievement, as shown in Table 3.5.

Table 3.5: Coefficients of Linear Regression: Emotional Engagement and Academic Achievement

\begin{tabular}{|c|c|c|c|c|c|c|c|c|c|}
\hline & \multirow{2}{*}{ Model } & \multicolumn{3}{|c|}{ Unstandardized Coefficients } & \multirow{2}{*}{$\begin{array}{c}\begin{array}{c}\text { Standardized } \\
\text { Coefficients }\end{array} \\
\text { Beta }\end{array}$} & \multirow[t]{2}{*}{$\mathrm{t}$} & \multirow[t]{2}{*}{ Sig. } & \multicolumn{2}{|c|}{$\begin{array}{l}95.0 \% \text { confidence interval } \\
\text { for B }\end{array}$} \\
\hline & & & & Std. Error & & & & Lower bo & per bound \\
\hline \multirow[b]{2}{*}{1} & \multirow{2}{*}{\multicolumn{2}{|c|}{$\begin{array}{c}\text { (Constant) } \\
\text { Emotional } \\
\text { engagement }\end{array}$}} & 1.497 & .440 & & 3.40 & .001 & .631 & 2.363 \\
\hline & & & .735 & .110 & .354 & 6.66 & .000 & .518 & .952 \\
\hline
\end{tabular}

A. Dependent variable: Academic achievement $(\mathrm{N}=312)$ 
Table 3.5 revealed that when the level of emotional engagement of the students in learning process was increased by one standard deviation, then academic achievement scores would increase by .354 standard deviation units. On the same note, increasing emotional engagement by one unit would result in an increase of academic achievement by .735 at $95 \%$ confidence interval of .518 and .952 lower and upper bound respectively. The findings from all these statistical measures establishing the relationship between emotional engagement and academic achievement in this study have shown to be similar to those of Lee (2014) who found a positive direct effect of emotional engagement on reading, Kamla-Raj and Ugur (2015) who discovered that academic performance of students had a positive relationship with emotional engagement, and Syokwaa et.al. (2014) whose study results showed a correlation between anxiety levels and academic achievement.

\section{Conclusion}

The results of this study indicated that there was a statistically significant though moderate positive correlation between emotional engagement and academic achievement. It was therefore concluded that student emotional engagement had a positive influence on the student academic achievement among the cohort that was involved in this study. Overall, majority of the students felt good about being in their schools, and they also felt safe. With feelings that their opinions were respected, majority had never considered dropping out of their schools, and if they had a chance to choose, majority would still remain in their schools. Class meetings, the suggestion box, guest speakers, guidance and counselling, school barazas and the promotion of child friendly environment emerged as very significant factors in the realization of students' emotional engagement, and satisfaction with the school environment and subsequently, improved academic achievement. The study recommended that teacher counsellors should adopt appropriate therapy techniques geared towards the enhancement of emotional engagement of all students in the schools of their jurisdiction in order to boost their chances of doing better in their studies.

\section{References}

Abbing, J. (2013).The Effect of Students' Engagement on Academic Achievement in Different Stages of their Academic Career from a Drop out Perspective. Published Bachelor's Thesis, University of Twente, Canada.

Afzal, M. T. \& Afzal, M. (2015). Comparison of Students' Satisfaction and Achievement at Secondary Level in Islamabad. American Journal of Educational Research, 3(12), 1524-1527.

Akey, T. M. (2006). School Context, Student Attitudes and Behaviour, and Academic Achievement: An Exploratory Analysis. New York. MDRC

Akomolafe, C. O. \& Adesua, V. O.(2015).The Classroom Environment: A Major Motivating Factor towards High Academic Performance of Senior Secondary School Students in South West Nigeria. Journal of Education and Practice. Vol.6, No.34, 2015 pp 17-21

Al-Alwan A. F. (2014). Modeling the Relations among Parental Involvement, School Engagement and Academic Performance of High School Students. International Education Studies; 7(4) pp 47-56.

Creswell, J. W. (2009). Research Design: Qualitative, Quantitative, and Mixed Methods Approaches. Thousand Oaks, CA: Sage Publications.

Dhaqane, M. K. and Afrah, N. A. (2016).Satisfaction of Students and Academic Performance in Benadir University. Journal of Education and Practice.Vol.7, No.24, pp 59-63

Evoh, C. J. (2007). Policy Networks and the Transformation of Secondary Education Through ICTs in Africa: The Prospects and Challenges of the NEPAD e- schools Initiative. In The International Journal of Education and Development Using ICT. 3(1) 2007 98-123

Fredricks, J.A., Blumenfeld, P.C., \& Paris, A.H. (2004). School engagement: Potential of the concept, state of the evidence. Review of Educational Research, 74(1), 59-109

Gray, J. A. \& DiLoreto, M (2016). The Effects of Student Engagement, Student Satisfaction, and Perceived Learning in Online Learning Environments. NCPEA International Journal of Educational Leadership Preparation, Vol. 11, No. 1 pp 1-20

Kamla-Raj \& Ugur Dogan(2015). Student Engagement, Academic Self-efficacy, and Academic Motivation as Predictors of Academic Performance. Anthropologist, 20(3): 553-561

Kpolovie, P. J. Joe, A. I. \& Okoto T.(2014). Academic Achievement Prediction: Role of Interest in Learning and Attitude towards School. International Journal of Humanities Social Sciences and Education (IJHSSE) Volume 1, Issue 11, pp 73-100 ISSN 2349-0373 (Print) \& ISSN 2349-0381 (Online) www.arcjournals.org 
Lawrence A.S. \& Vimala, A. (2012). School Environment and Academic Achievement of Standard IX Students. Journal of Educational and Instructional Studies in the World. Volume 2, issue 3, article 22, pp 210-215

Lee, J. S. (2014). The Relationship between Student Engagement and Academic Performance: Is It a Myth or Reality? Journal of Educational research.107 (3), 2014, pages 177-185 published on line $26^{\text {th }}$ March 2014. DOI:10.1080/00220671.2013.807491. ScienceDirect. 5th World Conference on Educational Sciences WCES 2013

Mageka R. \& Mahonge, C. (2013). Informal institutions and female students' school engagement: A case of Mvomero district ward schools. International Journal of Education and Research Vol. 1 No. 8 Pp1-12

Mai, Y. M. \& Alhoot, A. A. F. (2016). Modeling the Relation between Self-Esteem, Loneliness and Engagement as Factors of Children Achievement in Science. ISSN 2411-9563 (Print) ISSN 2312-8429 (Online) European Journal of Social Sciences Education and Research. Vol.6, Nr. 1 pp 107 - 120

Martin, A., \& Dowson, M. (2009). Interpersonal Relationships, Motivation, Engagement, and Achievement: Yields for Theory, Current Issues, and Educational Practice. Review of Educational Research, 79, 327-365.

Mauro, C. (2014). "Middle School Students' Perceptions on Academic Motivation and Student Engagement" Counselor Education Masters Theses. Paper 172.The College at Brockport, cball1@brockport.edu

Mo,Y.\& Singh K. (2008). Parents' Relationships and Involvement: Effects on Students' School Engagement and Performance. Research in Middle Level Education. 31(10) pp 1940-1976 Virginia Polytechnic Institute and State University Blacksburg, VA.

Okita D. O. (2014). Influence of Guidance and Counselling on Academic Performance of Students in Selected Public Secondary Schools in Molo Sub County, Nakuru County, Kenya. International Journal of Science and Research (IJSR) olume 3 Issue 12, 358

Payton, J.,Weissberg, R., Durlak, J., Dymnicki, A.B., Taylor, R.D., Schellinger, K.B., \& Pachan, M.(2008). The positive impact of social and emotional learning for kindergarten to eighth-grade students: Findings from three scientific reviews. Chicago, IL: Collaborative for Academic, Social, and Emotional Learning.

Perry, J. C. (2008). School Engagement among Urban Youth of Color: Criterion Pattern Effects of Vocational Exploration and Racial Identity. Journal of Career Development 34(4) pp 397-422

Plano-Clark, V., Huddleston-Casas, C., Churchill, S., O'Neil Green, D., \& Garrett, A., (2008). "Mixed Methods Approaches in Family Science Research" Educational Psychology Papers and Publications.Paper 81 Published in Journal of Family Issues 29:11 pp. 1543-1566; doi 10.1177/0192513X08318251

Purdul, J. N., Chege, E., \& Thinguri, R. (2014). A Study of Factors Affecting Students

Performance in Kenya:Certificate of Secondary Education in Public Secondary Schools in Amboseli Division, Loitokitok District, Kenya. Educational Research International. 3(5) pp 156-172

Rodriguez, J., \& Boutakidis, L. P. (2013). The Association between School Engagement and Achievement across Three Generations of Mexican American Students. Association of Mexican-American Educators (AMAE) Journal 7(1). Pp 5-12

Rumberger, R. (Ed.). (2008). Engaging High School Students in school. California: National Research Council.

Sagayadevan, V \& Jeyaraj, S. (2012). The Role of Emotional Engagement in Lecturer-Student Interaction and the Impact on Academic Outcomes of Student Achievement and Learning. Journal of the Scholarship of Teaching and Learning, 12(3), (pp. 1 - 30).

Suleman, Q. \& Hussain I. (2014). Effects of Classroom Physical Environment on the Academic Achievement Scores of Secondary School Students in Kohat Division, Pakistan International Journal of Learning \& Development Vol. 4, No. 1. Doi:10.5296/ijld.v4i1.5174 URL: http://dx.doi.org/10.5296/ijld.v4i1.5174

Syokwaa, K. A., Aloka, P.J. O., \& Ndunge, N. F. (2014). The Relationship between Anxiety Levels and Academic Achievement among Students in Selected Secondary Schools in Lang'ata District, Kenya. Journal of Educational and Social Research Vol. 4 No.3 pp 403-413.

Usaini, M. I.; Abubakar, N. B. \& Bichi, A. A. (2015). Influence of School Environment on Academic Performance of Secondary School Students in Kuala Terengganu, Malaysia. The American Journal of Innovative Research and Applied Sciences, Volume 1, No. 6 www.american-jiras.com (pp 203-209)

Weiss, C. C. \& García, E. (2012). Student Engagement and Academic Performance in México: Evidence and Puzzles from PISA. New York: Columbia University

Wonglorsaichon, B.,Wongwanich, S. \& Wiratchai, N. (2014). The Influence of Students School Engagement on Learning Achievement: A Structural Equation Modeling Analysis. Procedia - Social and Behavioral Sciences 116 ( 2014 ) $1748-1755$

Wormington, S. V., Corpus, J. H., and Anderson, K. G. (2011). A Person-Centered Investigation of Academic Motivation, Performance, and Engagement in a High School Setting. A Paper presented at the annual meeting of the American Educational Research Association, Reed College,New Orleans, LA, USA. 